\title{
Examination of the Dual-Band Microwave Wireless Access System Using Radio on Fiber Technique
}

\author{
Yasuhiro Kanaoka Member \\ Satoru Kashimura Member \\ Satoru Shimizu Non-member \\ (Kansai Electric Power Co., Inc.) \\ (Oki Electric Industry Co., Ltd.) \\ (Oki Electric Industry Co., Ltd.)
}

Keywords: Wireless Communication, Radio on Fiber, Wireless Access

A Radio on Fiber (ROF) technique has a great potential in wireless communication systems. In this paper, we performed fundamental examination of microwave wireless access systems based on Radio on Fiber.

Table 1. Specifications of the transmission system

\begin{tabular}{|l|l|}
\hline Frequency & $5.15 \sim 5.25 \mathrm{GHz}, 2.4 \sim 2.483 \mathrm{GHz}$ \\
\hline RF Input & $\begin{array}{l}10 \mathrm{dBm}(\text { Central Station) } \\
>-88 \mathrm{dBm}(\text { Base Station) }\end{array}$ \\
\hline RF Output & $>-88 \mathrm{dBm}(\mathrm{CS}), 10 \mathrm{dBm}(\mathrm{BS})$ \\
\hline Optical Output & $10 \mathrm{dBm}(\mathrm{CS}), 3 \mathrm{dBm}(\mathrm{BS})$ \\
\hline Optical Input & $>0 \mathrm{dBm}$ \\
\hline Wavelength & $1310 \mathrm{~nm}$ band \\
\hline
\end{tabular}

First, we designed and constructed examination systems applying dual band $(2.4 \mathrm{GHz}$ and $5 \mathrm{GHz})$ multi service transmission. The composition and parameters of the equipment is shown in Fig. 1 and Table 1 respectively. Transmission characteristic measurement of this equipment was performed for $2.4 \mathrm{GHz}$ and $5 \mathrm{GHz}$ band using wireless LAN systems based on IEEE802.11a $(5 \mathrm{GHz})$ and IEEE802.11g $(2.4 \mathrm{GHz})$. The results are shown in Fig. 3 (5GHz) and Fig. 4 (2.4GHz). Fig.3 and Fig.4 show that particular degradation of the transmission characteristics is not observed, when the ROF transmission equipment is added. As a result of transmission experiment, this ROF Equipment was confirmed to have sufficient performance.

Then, application of FP-LD was considered in order to reduce the system cost, and particular degradation of the transmission

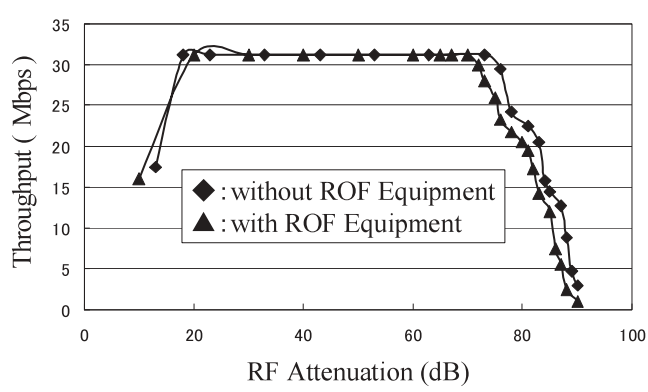

Fig. 3. Performance of the ROF system $(5 \mathrm{GHz})$

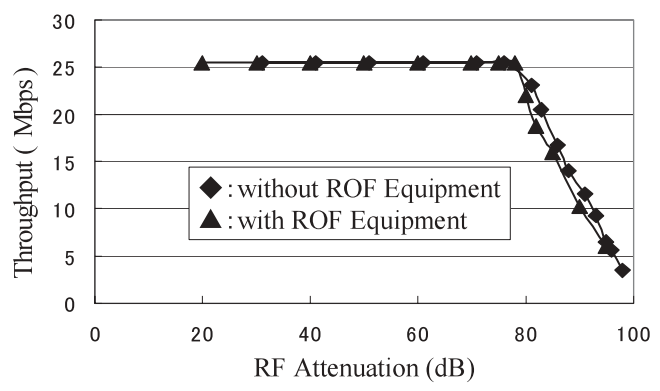

Fig. 4. Performance of the ROF system $(2.4 \mathrm{GHz})$

characteristics was not observed when FP-LD was used.

Finally, BIDI (Bi-directional) module which integrated LD and PD within one package was made for further cost reduction. By measuring the transmission performance, applying BIDI module to ROF systems was shown to be effective.

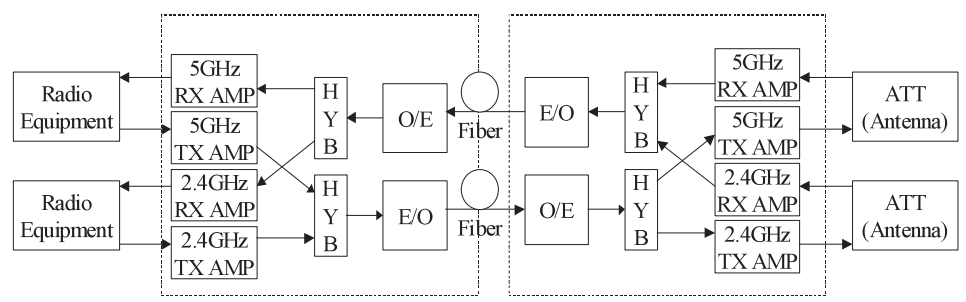

Fig.1. Composition of the transmission equipment 


\title{
光電波融合技術を用いたデュアルバンド \\ マイクロ波帯無線アクセスシステムの検討
}

\author{
正員金岡 泰弘* 正 員 樫村 聡** \\ 非会員 清水 聡**
}

\section{Examination of the Dual-Band Microwave Wireless Access System Using Radio on Fiber Technique}

Yasuhiro Kanaoka*, Member, Satoru Kashimura**, Member, Satoru Shimizu**, Non-member

A Radio on Fiber (ROF) technique has a great potential in wireless communication systems. In this paper, we performed fundamental examination of microwave wireless access systems based on Radio on Fiber.

First, we designed and constructed examination systems applying dual band $(2.4 \mathrm{GHz}$ and $5 \mathrm{GHz})$ multi service transmission systems and confirmed to have sufficient performance by transmission experiment.

Then, application of FP-LD (Fabry Perot Laser Diode) was considered in order to reduce the system cost, and most degradation of the transmission characteristics was not observed when FP-LD was used.

Finally, BIDI (Bi-directional) module which integrated LD and PD within one package was made for further cost reduction. By measuring the transmission performance, applying BIDI module to ROF systems was shown to be effective.

キーワード : 無線通信, 光電波融合技術, 無線アクセス

Keywords : Wireless Communication, Radio on Fiber, Wireless Access

\section{1. はじめに}

光電波融合技術(1)(2)は無線信号をそのままの形で光信号 に変換して伝送することにより, 光通信の持つ低損失性, 長距離伝送性，と無線通信の持つモバイル性の長所を併せ 持つ技術である。

この技術を用いた無線システムの構成を図 1 に示す。光 電波融合では無線機を親局(Central Station)に集中配置し, 無線機の信号をそのままの形で光信号に変換して子局 (Base Station)に伝送し, 子局は親局からの光信号を電気信 号に変換し電波発射に必要な所要パワーまで増幅するのみ の機能を持つ。このため光電波融合技術によって無線シス テムを構築すると, 子局の構成が簡素化されメンテナンス

\footnotetext{
* 関西電力 (株) 電力技術研究所

干661-0974 尼崎市若王子 3-11-20

Kansai Electric Power Co., Inc. Power Engineering R\&D Center,

3-11-20 Nakoji, Amagasaki-shi 661-0974

** 沖電気工業 (株) 無線技術研究開発部

干 239-0847 横須賀市光の丘 3-4

Oki Electric Industry Co., Ltd. Wireless Technology R\&D

Division

3-4 Hikarino-oka, Yokosuka-shi 239-0847
}

時, 無線機の取替時の作業が親局のみの作業で済むために, 工事回数は従来に比べて単純に 1 /子局の回数になる。ま た親局は建物内に設置されるため作業も容易になる。また 光信号を分岐, 合成することにより，1台の無線機の信号 を複数の子局から電波として発射することが可能になるた め, 1 台の無線機でサービスを提供することのできる範囲 を拡大寸ることが可能となる。言い換えると従来技術に比 べて少ない無線機数で無線サービスを提供することが可能

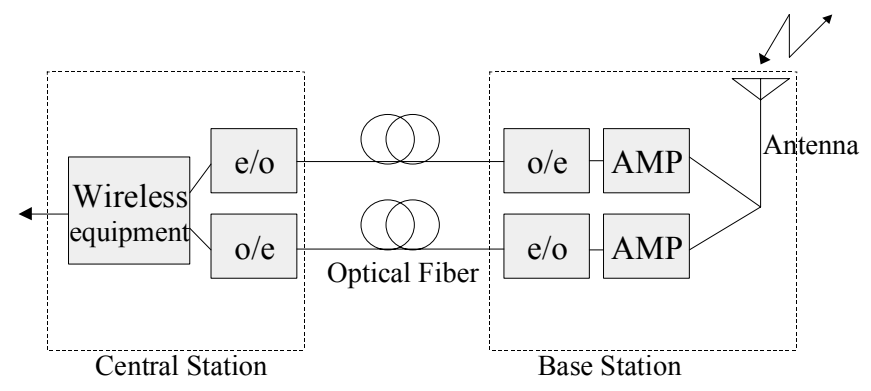

図 1 光電波融合技術を用いた無線システムの構成

Fig. 1. A composition of wireless system using radio on fiber technique. 
となる。このように光電波融合技術を適用することによっ て, 柔軟性と将来性に富んだ無線システムを構築すること ができる。

光電波融合技術の適用先として, 電波伝搬距離が短いミ リ波帯無線への適用(3)(4) なども研究されているが，より近 未来での光電波融合技術の実システムへの適用を考える場 合には，ミリ波帯無線は無線自体がまだ研究途上である。 このため本報告においてはミリ波帯無線よりも一般的なマ イクロ波帯無線, その中でも無線規格のグレードアップに 伴う更新の頻度が高いと考えられる無線アクセスシステム への適用を検討した。

検討の中では，はじめにマイクロ波帯無線アクセスシス テムとして用いられる $2.4 \mathrm{GHz}$ 帯と $5 \mathrm{GHz}$ 帯のデュアルバ ンドを伝送する光電波融合技術による伝送装置を試作し, 複数の無線システムへの対応性を確認するために，2つの 周波数帯それぞれにおいて 2 種類の無線システムの伝送特 性を測定した。次に試作した装置を実サービスに適用する 際に問題となる伝送装置のコストを低減するために, 電気一 光変換部分に安価な FP-LDを用いた伝送装置を試作し，伝 送特性測定によって, FP-LD 採用の有効性を検討した。最 後に更なるコスト低減のために, 光-電気, 電気-光変換部を 一体化したモジュールを試作した。

\section{2. 光電波融合技術を用いたマイクロ波帯無線ア クセスシステム用伝送装置}

〈2·1〉 伝送装置の概要 マイクロ波帯を用いた無線 アクセスシステムは, $2.4 \mathrm{GHz}$ 帯を用いるものと, $5 \mathrm{GHz}$ 帯 を用いるものがある。伝送装置の試作にあたっては, (1) 2 つの周波数帯の無線システムを伝送可能とする, (2)光電気 変換方式はできるだけ廉価な方式を用いる, (3)将来的に光 信号の部分で分岐を行うことを視野に入れた装置とする, の 3 点を考慮して設計した。

表 1 に試作した伝送装置の主要諸元を, 図 2 に装置の構 成を示す(5)。

表 1 伝送装置の主要諸元

Table 1. Specifications of the transmission system.

\begin{tabular}{|l|l|}
\hline Frequency & $5.15 \sim 5.25 \mathrm{GHz}, 2.4 \sim 2.483 \mathrm{GHz}$ \\
\hline RF Input & $\begin{array}{l}10 \mathrm{dBm}(\mathrm{Central} \text { Station }) \\
>-88 \mathrm{dBm}(\text { Base Station) }\end{array}$ \\
\hline RF Output & $>-88 \mathrm{dBm}(\mathrm{CS}), 10 \mathrm{dBm}(\mathrm{BS})$ \\
\hline Optical Output & $10 \mathrm{dBm}(\mathrm{CS}), 3 \mathrm{dBm}(\mathrm{BS})$ \\
\hline Optical Input & $>0 \mathrm{dBm}$ \\
\hline Wavelength & $1310 \mathrm{~nm}$ band \\
\hline RIN & $<-150 \mathrm{~dB} / \mathrm{Hz}$ \\
\hline $\begin{array}{l}\text { Conversion } \\
\text { efficiency:LD }\end{array}$ & $0.1 \sim 0.3 \mathrm{~mW} / \mathrm{mA}$ \\
\hline $\begin{array}{l}\text { Conversion } \\
\text { efficiency:PD }\end{array}$ & $0.8 \mathrm{~A} / \mathrm{W}$ \\
\hline $\begin{array}{l}\text { Equivalent noise } \\
\text { current density:PD }\end{array}$ & $<20 \mathrm{pA} / \sqrt{\mathrm{Hz}}(5 \mathrm{GHz}),<10 \mathrm{pA} / \sqrt{\mathrm{Hz}}(2.4 \mathrm{GHz})$ \\
\hline
\end{tabular}

本装置は $2.4 \mathrm{GHz}$ 帯と $5 \mathrm{GHz}$ 帯無線システムのデュアル バンド同時伝送を行うため, 高周波増幅回路は各周波数帯 毎の独立構成とし, 両周波数帯の合成, 分離は電気光变換 前および光電気変換後に行った。次に電気光変換方式は, $\mathrm{LD}$ の直接変調方式と, 光変調器を用いた外部変調方式が考 えられ，マイクロ波帯を伝送するシステムの場合はいずれ の方式も適用可能であるが，今回の試作に当たっては，コ スト面から廉価な方式である, LD による直接変調方式を用 いた。また LDには携帯電話信号等のアナログ伝送用に開発 された DFB-LD（Distributed Feed Back Laser Diode）を 用いた。

〈2·2〉無線システムの伝送特性＼cjkstart現在マイクロ波帯 無線アクセスシステムに用いられる専用の標準規格はまだ 存在せず, 独自規格を用いてサービスを行われている場合 を除けば, $2.4 \mathrm{GHz}$ 帯では IEEE802.11b, IEEE802.11g 規 格による無線システムで, $5 \mathrm{GHz}$ 帯においては IEEE802.11a と Hiswan 規格による無線システムにてサー ビスが行われている。また将来的にはこれらの規格のグレ ードアップされた規格によってサービスが行われること,

IEEE802.16, IEEE802.20 で規格制定作業が行われている 無線システムによってサービスが行われること等が考えら れる。

ここでは，今回試作した伝送装置がマルチバンドにおい てマルチサービスに対応できることを確認するため, 各周 波数毎に複数の無線システムの伝送特性を測定した。

伝送特性の測定に使用する無線システムは, 入手可能な ものから一般的なものを選択するという観点から，

IEEE802.11a, Hiswan, IEEE802.11b, および IEEE802.11g 準拠の市販無線システムを用いることとした。

測定は図 3 に示す実験構成によって実施した。伝送特性 は光伝送装置の子局と無線機の間を高周波減衰器によって 接続し, 高周波減衰量に対する伝送スループット特性を測 定することによって評価した。なお，高周波減衰量 20,40 , $60,80 \mathrm{~dB}$ は自由空間損失での伝送距離, 約 $0.1 \mathrm{~m}, 1 \mathrm{~m}, 10 \mathrm{~m}$ $100 \mathrm{~m}(2.4 \mathrm{GHz})$ および約 $0.05 \mathrm{~m}, 0.5 \mathrm{~m}, 5 \mathrm{~m}, 50 \mathrm{~m}(5 \mathrm{GHz})$ に相当する。なお伝送スループット特性以外には，スプリ アス信号が $2.4 \mathrm{GHz}$ 帯, $5 \mathrm{GHz}$ 帯それぞれの高周波増幅器に て抑えられていることを確認した。

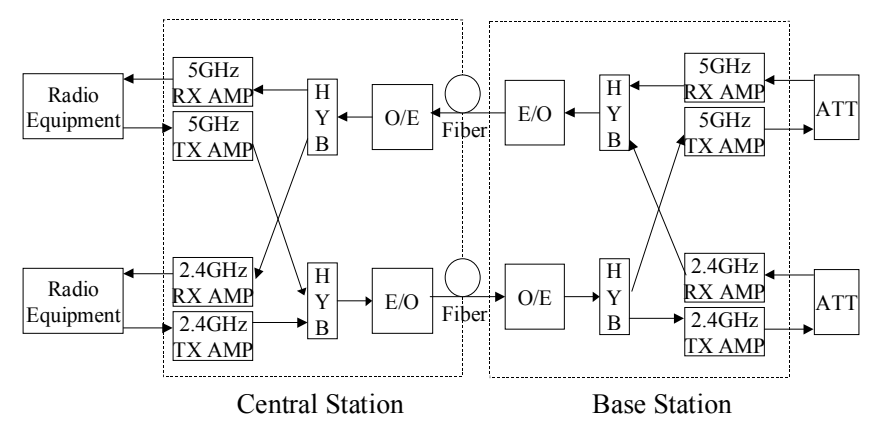

図 2 伝送装置の構成

Fig. 2. Composition of the transmission system. 


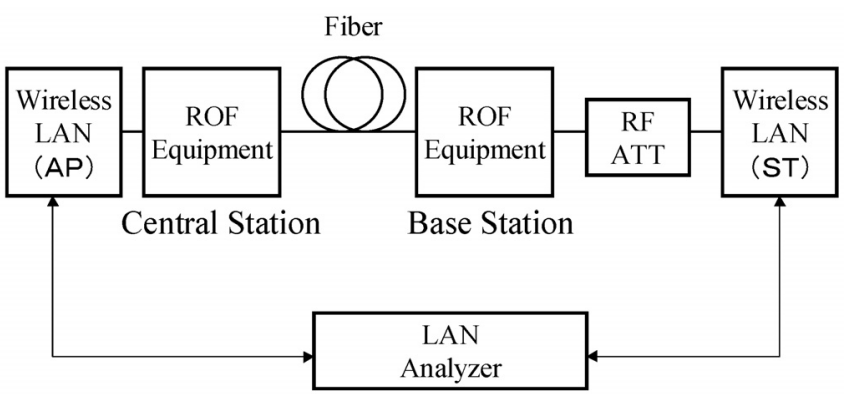

図 3 実験構成

Fig. 3. Experimental setup.

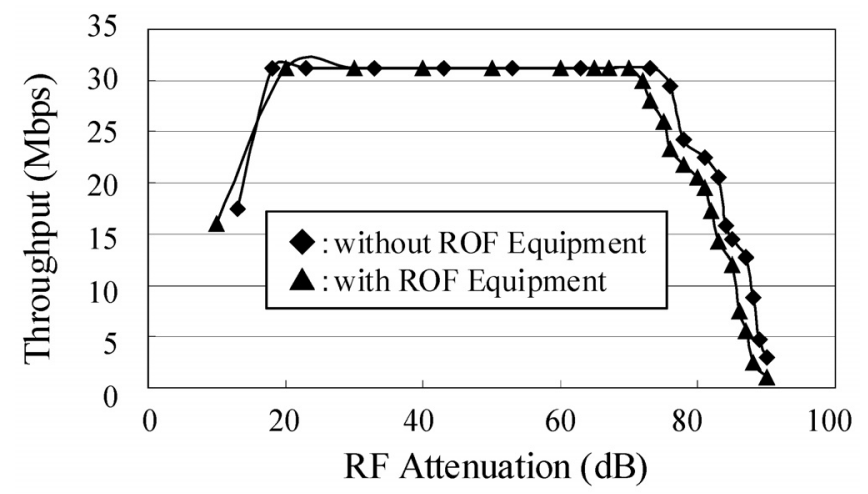

図 4 ROF 伝送装置の特性（IEEE802.11a）

Fig. 4. Performance of the ROF system (IEEE802.11a).

はじめに親局－子局の光伝送装置間を光コードによって 直接接続した場合の親局から子局方向の伝送特性を，無線 機を光電波融合による伝送装置を介さないで直接減衰器を 用いて接続した場合の特性とあわせて図 4 から図 7 に示 す。但し IEEE802.11bのみについては，実験環境の問題か ら，光電波融合による光伝送装置の親局一子局間での高周 波漏れによって光コードを用いた直接接続の特性が測定で きなかったため, 光コードの代わりに $400 \mathrm{~m}$ の光ファイバ を接続した場合の特性を示している。図 4 から図 6 におい て高周波減衰量が $20 \mathrm{~dB}$ 程度と少ない領域でスループット が劣化している。これは自由空間損失での伝送距離 $0.1 \mathrm{~m}(2.4 \mathrm{GHz}), 0.05 \mathrm{~m}(5 \mathrm{GHz})$ が減衰量 $20 \mathrm{~dB}$ に相当するこ とから，無線機の近接により無線機入力過大となって伝送 特性が劣化することと同様の現象が発生したためと考えら れる。また高周波減衰量に対する伝送速度，および伝送速 度が劣化する減衰量が図毎に異なるのは，それぞれの無線 機の通信可能距離が異なるためである。

図 5 に示される Hiswan の特性が悪いのは無線機自体が 原因である。これは Hiswan の無線機を用いて実空間で無 線伝送実験を行い，伝送距離 $10 \mathrm{~m}$ 以上で伝送速度が劣化し たことにより確認した。次に図 4 から図 7 までそれぞれに おいて，無線機同士を直接接続した場合と，光電波融合に よる伝送装置を介した場合の伝送特性を比較した。その結 果伝送装置を介しても最大伝送速度は劣化せず，伝送速度

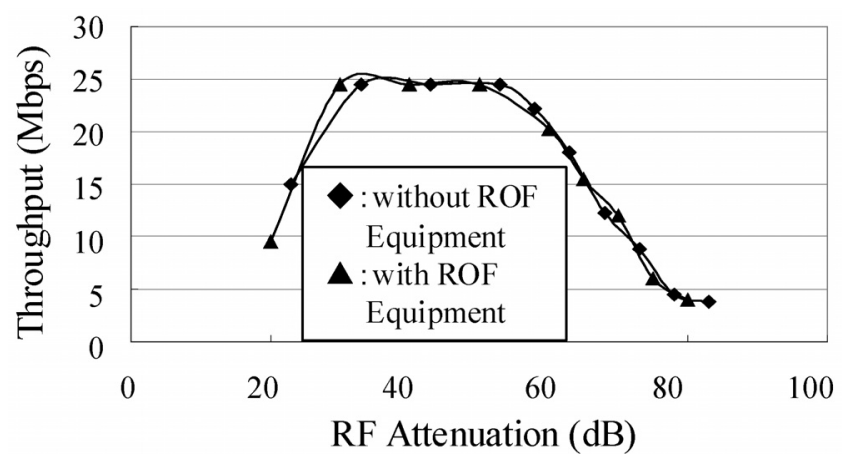

図 5 ROF 伝送装置の特性（Hiswan）

Fig. 5. Performance of ROF system (Hiswan).

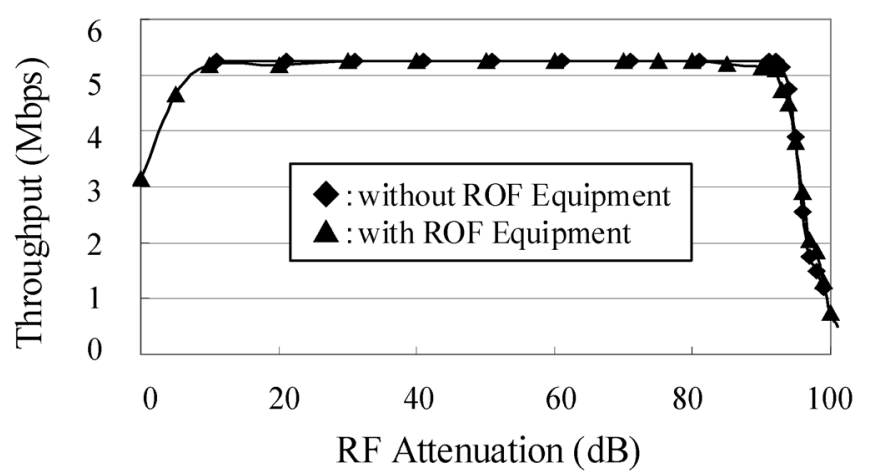

図 6 ROF 伝送装置の特性（IEEE802.11b）

Fig. 6. Performance of ROF system (IEEE802.11b).

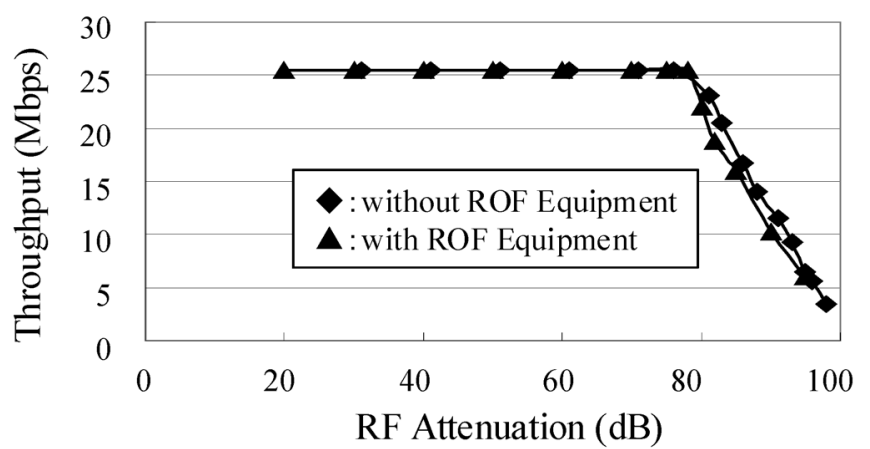

図 7 ROF 伝送装置の特性（IEEE802.11g）

Fig. 7. Performance of ROF system (IEEE802.11g).

が劣化する場合の減衰量の差も $3 \mathrm{~dB}$ 以内と, 複数の周波数 帯で，それぞれ複数の無線システムを用いた場合において， 光電波融合による伝送装置を付加することによる伝送特性 の劣化は実用上十分に問題とならないレベルであった。

次に光伝送装置の親局－子局間を光ファイバで接続し， 光ファイバの長さを変えた場合の無線システムの伝送特性 を測定した。その結果を図 8 から図 11 に示す。

$5 \mathrm{GHz}$ 帯無線システムの IEEE802.11a（図 8 ）では光フ アイバ長を変化させたとき, ファイバ長が $800 \mathrm{~m}$ では伝送 特性の劣化は観測されず, $900 \mathrm{~m}$ 以上で特性の劣化が観測さ 


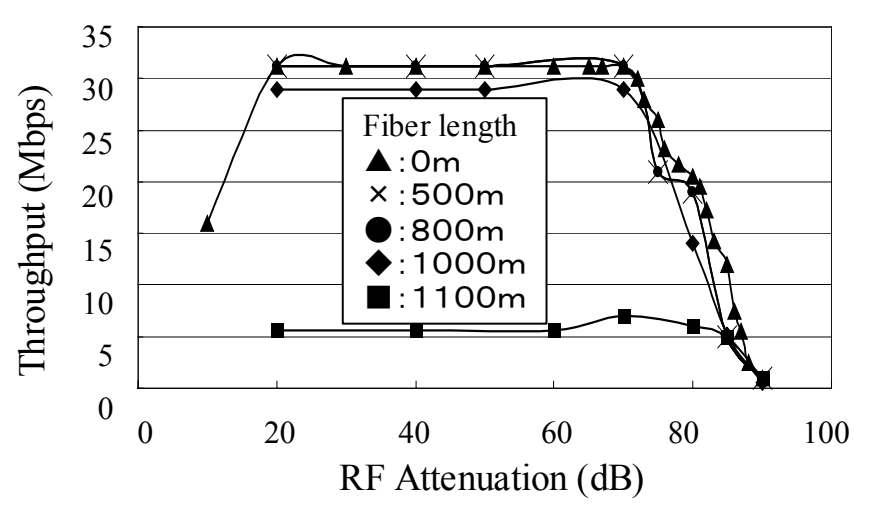

図 8 光ファイバ伝送距離特性（IEEE802.11a）

Fig. 8. Optical fiber transmission characteristic (IEEE802.11a).

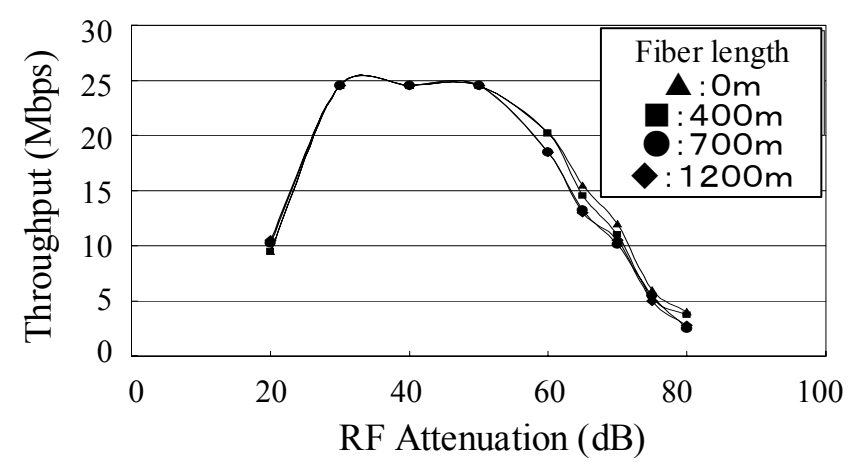

図 9 光ファイバ伝送距離特性 (Hiswan)

Fig. 9. Optical fiber transmission characteristic (Hiswan).

れた。Hiswan（図 9) では光ファイバ長が $1200 m$ まで特 性の劣化がなく, それ以上では通信不可能であった。次に $2.4 \mathrm{GHz}$ 帯の IEEE802.11 b（図 10）においては光ファイバ 長 $6.4 \mathrm{~km}$ まで特性の劣化がなく, それ以上では通信不可能, IEEE $802.11 \mathrm{~g}$ においては（図 11）光ファイバ長 $500 \mathrm{~m}$ まで 伝送特性の劣化はなく, ファイバ長をそれ以上に延長した 場合に特性が徐々に劣化し始めた。

最後に光ファイバを $400 \mathrm{~m}$, 高周波減衰量を $40 \mathrm{~dB}$ として, $5 \mathrm{GHz}$ 帯の IEEE802.11a と 2.4GHz 帯の IEEE802.11b 同 時伝送実験を行った結果, 単独伝送時と同じ伝送速度が得 られた。

〈2·3〉無線システムの光ファイバ伝送距離特性 前 項の実験結果では, $2.4 \mathrm{GHz}$ 帯, IEEE $802.11 \mathrm{~b}$ 以外の無線 システムについて, 光ファイバの伝送距離がいずれも $1 \mathrm{~km}$ 以下であった。これに対して無線システムを構築する場合, 親局は無線サービスを提供する事業者の局舎に設置するこ とが考えられ，その配置状況を考えると，光ファイバを伝 送できる距離は数 $\mathrm{km}$ 以上が望ましいと推定することがで きる。

ここでは, IEEE802.11a について検討した。伝送距離の 短い原因は, IEEE802.11a の規格が, 主に室内での伝送を

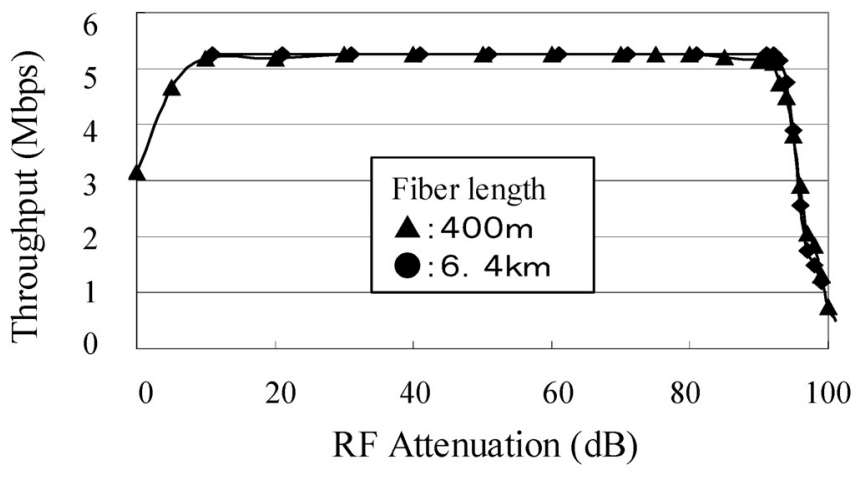

図 10 光ファイバ伝送距離特性（IEEE802.11b）

Fig. 10. Optical fiber transmission characteristic (IEEE802.11b).

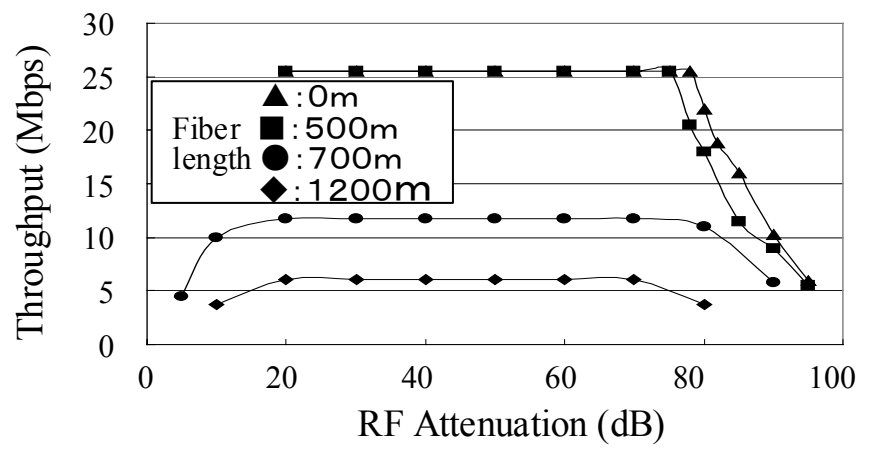

図 11 光ファイバ伝送距離特性 (IEEE802.11g)

Fig. 11. Optical fiber transmission characteristic (IEEE802.11g).

想定して策定されており，プロトコル上そもそも長距離の 伝送を想定されていないことが考えられる。これはプロト コルのうち ACK のタイミングを変更することで, IEEE802.11a を光電波融合技術によって $3 \mathrm{~km}$ の光ファイ バを伝送させている例(6)があることからも確認できる。

以上のように, 光電波融合技術を用いた無線システムを 試作して伝送特性評価を行った結果, 複数の周波数帯にお ける複数の無線システムを特性の劣化がなく伝送できるこ とが確認できた。但し IEEE $802.11 b$ 以外の無線システムで は伝送距離が $1 \mathrm{~km}$ 以下であり伝送距離の長距離化に問題が あることが明らかになった。

\section{3. 伝送装置の低コスト化検討}

〈3·1〉伝送装置への FP-LD の適用光電波融合技術 を用いたマイクロ波帯無線アクセスシステムにより無線サ 一ビスを提供する場合，無線機は親局に集中配置される。 このため無線機の取替時には親局での作業で済み, 無線機 を各子局に分散配置する従来技術に対して，取替に要する 費用を低く抑えることが可能となる。しかし, サービス開 始のための初期コストについては, マイクロ波帯でのサー ビスでは標準規格に基づく量産化されている無線機を用い ることが考えられるため, 光部分での分岐を行って 1 台の 
無線機のサービスエリアを拡大した場合においてさえも， 現状では従来技術を用いてサービスを開始する場合の初期 コストの方が，光電波融合技術を用いる場合よりも低いこ とが十分考えられる。このため光電波融合技術による伝送 装置, とりわけ子局装置の低コスト化が必要となる。

伝送装置の中でのコストがかかっている部分としては電 気一光変換部があげられる。これは光電波融合技術による伝 送装置では，CNR が回線品質に大きく影響を与えるため， 低雑音の DFB-LD を用いているためである。

DFB-LD より安価な LD として, 構造が DFB-LD より簡 単で，かつ広く使用されている FP-LD がある。FP-LD は DFB-LD と比較して，コスト面では有利であるが，複数の スペクトルで発振することから，雑音特性面で不利である。 2 項の伝送装置の DFB-LD を FP-LDに置き換えた場合の光 部諸元を表 2 に示す。 RIN（相対雑音強度）が DFB-LD 使 用時は両周波数とも $-150 \mathrm{~dB} / \mathrm{Hz}$ 以下であるのに対して, FP-LD を用いることによって約 $10 \mathrm{~dB}$ の劣化が見られる。 他のパラメータは DFB-LD 使用時と変わらない。

光電波融合技術を用いた光電気変換部の CNR は

$$
C / N=\frac{o m i{ }^{2} \times\left(P_{o p} \times \eta\right)^{2} / 2}{\left\{\mathrm{RIN} \times\left(P_{o p} \times \eta\right)^{2}+2 e\left(P_{o p} \times \eta\right)+\left\langle I_{t h}\right\rangle^{2}\right\} \mathrm{BW}}
$$

$o m i: \mathrm{LD}$ 部変調度, $\mathrm{RIN}: \mathrm{LD}$ 強度雑音,

$P_{o p}:$ 受光レベル $, \eta: \mathrm{PD}$ の変換効率,

$e:$ 電子電荷, $I_{t h}: \mathrm{PD}$ 部等価雑音電流密度,

$B W:$ 帯域

表 2 光部主要諸元

Table 2. Parameters of optical components.

\begin{tabular}{|c|c|c|}
\hline & $5 \mathrm{GHz}$ band & $2.4 \mathrm{GHz}$ band \\
\hline Output : LD & $2 \mathrm{~mW}$ & $2 \mathrm{~mW}$ \\
\hline RIN : LD & $<-140 \mathrm{~dB} / \mathrm{Hz}$ & $<-140 \mathrm{~dB} / \mathrm{Hz}$ \\
\hline $\begin{array}{c}\text { Conversion } \\
\text { efficiency: LD }\end{array}$ & $0.1 \sim 0.3 \mathrm{~mW} / \mathrm{mA}$ & $0.1 \sim 0.3 \mathrm{~mW} / \mathrm{mA}$ \\
\hline $\begin{array}{c}\text { Conversion } \\
\text { efficiency : PD }\end{array}$ & $0.8 \mathrm{~A} / \mathrm{W}$ & $0.8 \mathrm{~A} / \mathrm{W}$ \\
\hline $\begin{array}{c}\text { Equivalent } \\
\text { noise current } \\
\text { density : PD }\end{array}$ & $<20 \mathrm{pA} / \sqrt{H z}$ & $<10 \mathrm{pA} / \sqrt{H z}$ \\
\hline $\begin{array}{c}\text { Input : PD } \\
\text { Band width }\end{array}$ & $16.8 \mathrm{mHz}$ & $1 \mathrm{~mW}$ \\
\hline
\end{tabular}

表 3 光電気変換部の $\mathrm{CNR}$ 特性（設計值）

Table 3. CNR characteristics of optical components (design value).

\begin{tabular}{|c|c|c|}
\hline & CNR $(5 \mathrm{GHz})$ & CNR $(2.4 \mathrm{GHz})$ \\
\hline DFB-LD & $27.2 \mathrm{~dB}$ & $32.1 \mathrm{~dB}$ \\
\hline FP-LD & $24.6 \mathrm{~dB}$ & $29.4 \mathrm{~dB}$ \\
\hline
\end{tabular}
(RF input: $-65 \mathrm{dBm})$
で算出される(7)。式中の変数のうち $\mathrm{LD}, \mathrm{PD}$ 固有の值 $(\mathrm{RIN}$, $\left.\eta, I_{t h}\right)$ とシステムに依存する值（BW）は調整不可能であ るが, 調整可能な omi の值を変更することによって, 2 項 の装置に準じた CNR 特性を有する伝送装置を設計した。

$\langle 3 \cdot 2\rangle$ 伝送装置の特性伝送装置における光電気変換 部の CNR 特性の設計值を表 3 に示す。この值は使用する無 線機に適正な受信電力である $-65 \mathrm{dBm}$ が入力された場合に 式(1)から算出される CNR 特性で, FP-LD 使用時の omi を $5 \mathrm{GHz}$ 帯では DFB-LD 使用時の $0.5 \%$ から $1 \%$ に， $2.4 \mathrm{GHz}$ 帯ではDFB-LD 使用時の $1 \%$ から $2 \%$, それぞれ変更した。 これにより DFB-LD 使用時に対して $5 \mathrm{GH} \mathrm{z}$ 帯で $2.6 \mathrm{~dB}$, $2.4 \mathrm{GHz}$ 帯で $2.7 \mathrm{~dB}$ の差しか有さない装置の設計が可能で あった。

この設計に基づいて FP-LD を適用した光電波融合技術に よる光伝送装置の子局を試作した ${ }^{(8)}$ 。装置の構成は図 2 に示 すものと同じであり，この装置を用いて図 3 の実験構成に て伝送特性を測定した。ここで, 送信電力は $3 \mathrm{dBm}$ とした。 従って, RF Attenuation の值が $68 \mathrm{~dB}$ のところが, 設計值 における所望入力である- $65 \mathrm{dBm}$ に相当する。

実験は光ファイバ長を $400 \mathrm{~m}$ とし, 無線装置システムに は $5 \mathrm{GHz}$ 帯: IEEE802.11a 準拠, $2.4 \mathrm{GHz}$ 帯: IEEE802.11g

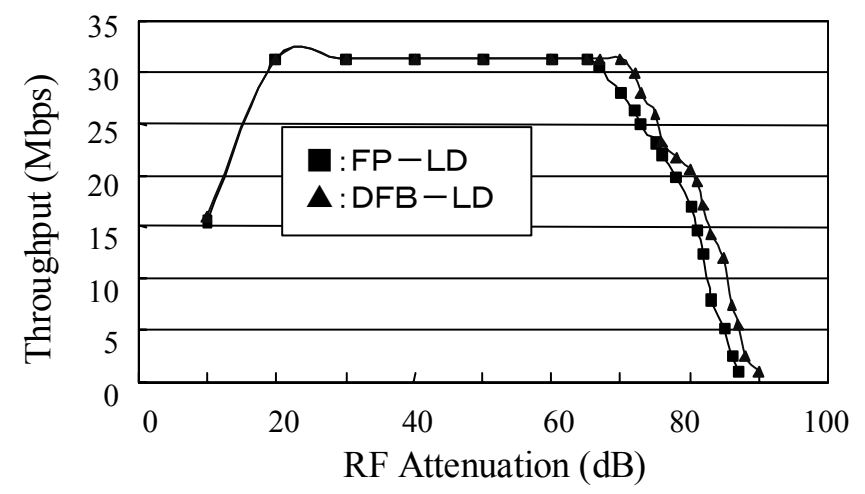

図 12 FP-LD 適用時の伝送特性 $(5 \mathrm{GHz})$

Fig. 12. Transmission characteristics with FP-LD $(5 \mathrm{GHz})$.

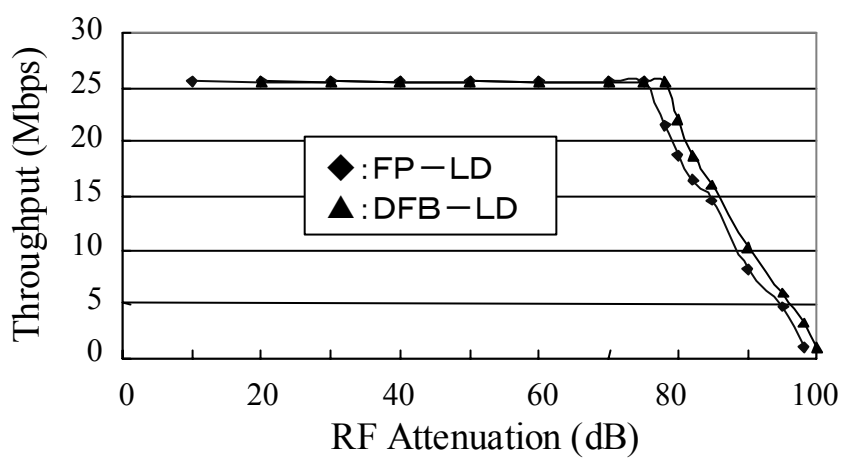

図 13 FP-LD 適用時の伝送特性 $(2.4 \mathrm{GHz})$

Fig. 13. Transmission characteristics with FP-LD $(2.4 \mathrm{GHz})$. 
準拠の市販無線機を使用した。伝送特性測定結果を DFB-LD 適用時とあわせて, 図 $12(5 \mathrm{GHz}$ 帯), 図 $13(2.4 \mathrm{GHz}$ 帯) に示す。 $5 \mathrm{GHz}$ 帯の場合は, スループットが劣化する RF Attenuation の值が 65〜 70dB と設計值とほぼ同じにな った。一方, $2.4 \mathrm{GHz}$ 帯は, さらに信号を減衰させても高ス ループットが得られている。これは, $2.4 \mathrm{GHz}$ 帯の無線機が 設計值とした $-65 \mathrm{dBm}$ 以下の入力でも十分な通信特性が得 られるようになっているためである。 $5 \mathrm{GHz}$ 帯の伝送特性に おいては, FP-LD を用いた場合と DFB-LDを用いた場合を 比較すると, 最大伝送速度は共に $31 \mathrm{Mbps}$ で両者の間に違 いはなく, 伝送速度が劣化する場合の減衰量の差が, FP-LD と DFB-LD との設計值 CNR の差分とほぼ同等の $1 \sim 3 \mathrm{~dB}$ であった。2.4GHz 帯の伝送特性（図 13）においても，最 大伝送速度は FP-LD， DFB-LD のいずれを用いても同等 （26Mbps）で，伝送速度が劣化する場合の減衰量の差が 2 種の LD を用いたときの設計值における CNRの差分とほぼ 同等の $1 \sim 2 \mathrm{~dB}$ であった。

次に光ファイバの長さを変えたときの伝送特性の変化に ついては，LD を FP-LD にしても伝送距離特性の変化は観 測されなかった。

伝送特性の測定から安価な FP-LD を用いても DFB-LD を用いた場合とほぼ同等の特性を得られたため，低コスト な光電波融合技術による伝送システムの構築において，電 気-光変換部への FP-LD 適用の有効性が確認できた。

〈3.3〉 FP-LD を用いた光電気, 電気光一体型モジュー ルの試作＼cjkstart伝送装置の更なる低コスト化を行うために, FP-LD を用いて図 14 に示亦構成の, 光-電気 (PD), 電気一 光変換部 $(\mathrm{LD})$ を一体化モジュール (BIDI (Bi-directional) Module）を試作した。なお試作にあたっては表 2 に示す諸 元を持つ $\mathrm{PD}, \mathrm{LD}$ を用いた。このモジュールは送受信を $1.5 \mu \mathrm{m}$ 帯と $1.3 \mu \mathrm{m}$ 帯の波長多重によって多重化しているた めに, 伝送に必要な光ファイバが通常の半分の 1 心となり, モジュールの使用によりシステムの低コスト化を図ること が可能となる。

このモジュールを用いて図 15 に示す光伝送装置子局を試 作し(9)，伝送特性の測定を行った。光ファイバ長を $400 \mathrm{~m}$,

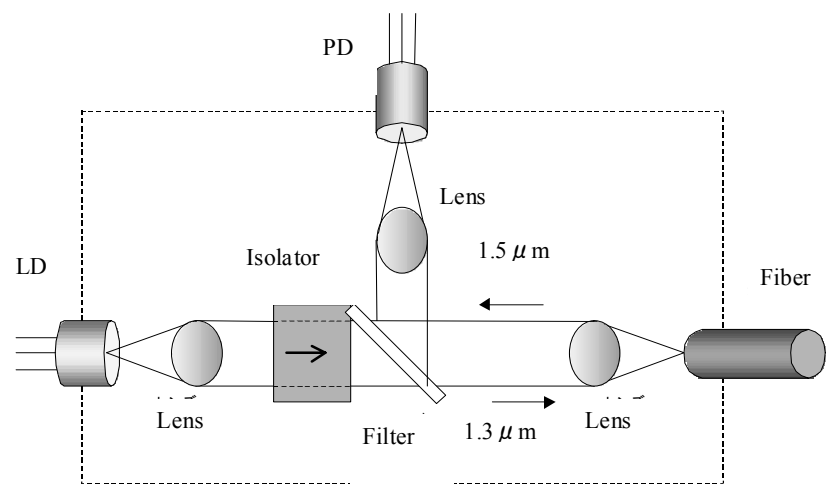

図 14 BIDI モジュールの構造

Fig. 14. Composition of the BIDI module.
無線システムを IEEE802.11a（5GHz 帯), IEEE802.11g ( $2.4 \mathrm{GHz}$ 帯) としたときの, 伝送特性を図 16 (5GHz 帯), 図 $17(2.4 \mathrm{GHz}$ 帯) にモジュール化を行わなず, 波長多重 伝送も行わない場合の特性と併せて示す。 $5 \mathrm{GHz}$ 帯 $2.4 \mathrm{GHz}$ 帯ともモジュール化を行わない場合との特性差は数 $\mathrm{dB}$ 程 度に収まっており，モジュール化による特性劣化はほとん どないことが確認できた。また光ファイバの伝送距離を変 化させた場合の特性変化も観測はされなかった。

モジュール化を行わずに FP-LD を適用した場合の特性

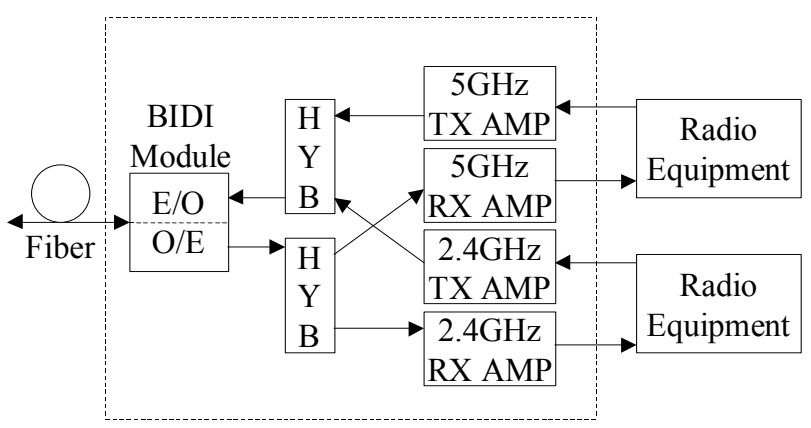

図 15 伝送装置の構成

Fig. 15. Composition of the transmission Equipment.

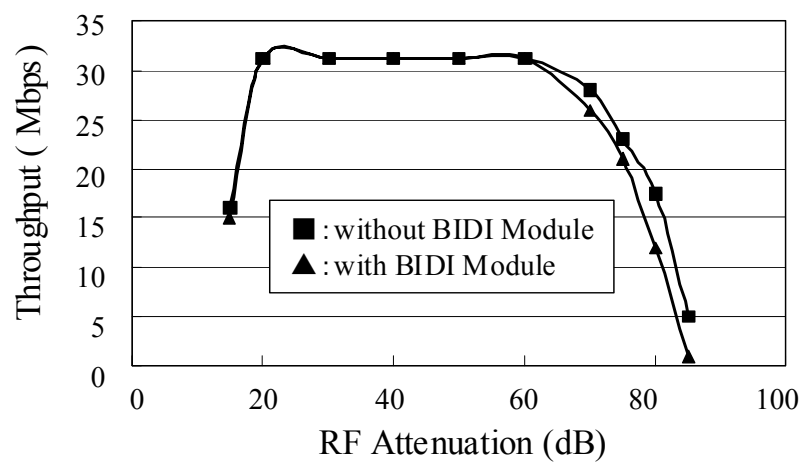

図 16 BIDI モジュール適用時の伝送特性 $(5 \mathrm{GHz})$

Fig. 16. Transmission characteristics with BIDI Module(5GHz).

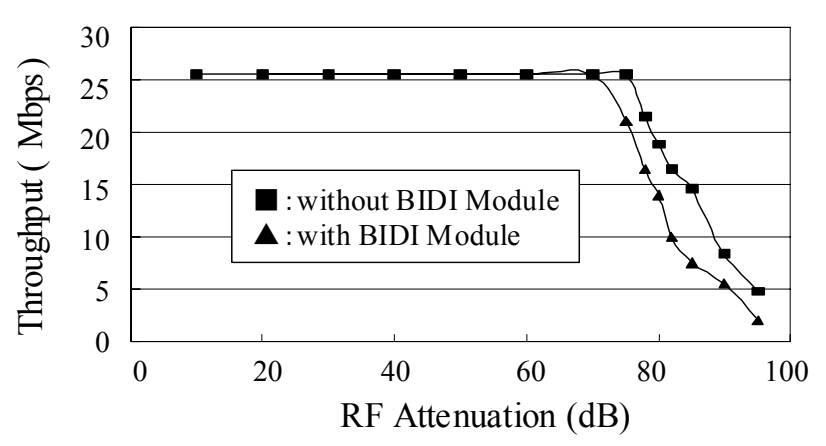

図 17 BIDI モジュール適用時の伝送特性 $(2.4 \mathrm{GHz})$

Fig. 17. Transmission characteristics with BIDI Module(2.4GHz). 
が，DFB-LD を適用した場合の特性とほぼ同等であること から，FP-LD を適用し，さらに，モジュール化を行った場 合においても，伝送特性はDFB-LD 適用時とほぼ同等であ るといえ, 光電気変換部分のモジュール化が伝送装置の更 なる低コスト化に有効であることが確認できた。

\section{4. むすび}

光電波融合技術を用いて, $2.4 \mathrm{GHz}$ 帯と $5 \mathrm{GHz}$ 帯のデュア ルバンドを伝送するマイクロ波帯無線アクセスシステムを 検討した。

従来，このようなシステムを構築する場合，電気光交換 部にアナログ伝送用に設計された DFB-LD を用いることが 一般的であった。しかしながら，アナログ用の DFB-LD は 高価であるために光電波融合技術普及の障害要因の一つに なっていた。そこで本論文では安価な FP-LD を用いたシス テムを構築して特性を評価した。そこで, 本論文では安価 な FP-LD を用いて，さらにこの LD と PD を一体化した BIDI モジュールにてシステムを構築し, その特性を評価し た。その結果，FP-LD 組込んだ BIDI モジュールを用いた 場合, 従来に比べて伝送速度が低下寸る減衰量で評価して $6 \mathrm{~dB}$ 以内の劣化に留まることが分かった。これは，実用上， 十分に無視できる值である。以上の実験及び，考察により， 光電波融合技術を用いたマイクロ波帯無線アクセスシステ ムに FP-LD を組込んだ BIDI モジュールを使うことは全く 問題がないことを定量的に示した。

今後は光ファイバの伝送距離延長について解決を図って いくとと共に，分岐合成等を含んだシステム全体の検討を 実施する予定である。

(平成 16 年 11 月 1 日受付, 平成 17 年 9 月 12 日再受付)

\section{文献}

(1) H. Al-Raweshidy, and S. Komaki, ed., Radio over Fiber Technologies for Mobile Radio Communications Networks, Artech House Publishers, Boston (2002)

(2) D. Wake : "Trends and Prospects for Radio over Fibre Picocells", Int. Topical Mtg. on Microwave Photonics, MWP'02, Tech. Digest pp.21-24, Awaji, Japan (2002-11)

(3) T. Kuri, K. Kitayama, A. Stohr, and Y. Ogawa : "Fiber-optic Millimeter-wave downlink system using $60 \mathrm{GHz}$-band external modulation”, IEEE Trans. Microwave Technol., Vol.17, No.5, pp.799-806 (1999-5)

(4) M. Fujise : "Study on System Concepts for Multiple Services Wireless Communications based on ROF", IEICE Trans. On Commun., Vol.J84-B, No.4, pp.655-665 (2001-4) (in Japanese) 藤瀬雅行：「ROF マルチサービス無線システムについて」, 信学論 B, J84-B, 4, pp.655-665 (2001-4)

(5) Y.Kanaoka : "An Examination of an Application for a Radio on Fiber Technique to Micro Wave Band Wireless Access Systems", IEEJ Com. Society, Report, CMN-04-06, pp.27-30 (2004-1) (in Japanese)

金岡泰弘:「光電波融合技術のマイクロ波带無線アクセスシステムへ の適用に関する一検討」, 電気通信研資, CMN-04-06, pp.27-30 (2004-1)

(6) T. Niiho, H. Sasai, K. Tanaka, K. Utsumi, and S. Morikura :
"Optical Transmission Performance of W-LAN Signal Specified in IEEE802.11a using Radio on Fiber Technique", Technical Report of IEICE RCS 2003-29 (2003-05) (in Japanese) 新保努武·笹井裕之・田中和夫·内海邦昭·森倉 晋 :「Radio on Fiber 技術を用いた IEEE 802.11a 信号の光伝送実験」, 信学技報, RCS2003-29 (2003-5)

(7) S. Shibuya, K, Emura, and T. Kanai : "Optical fiber transmission of RF signal for microcellular mobile communication system", Technical Report of IEICE SAT90 29-40 pp.19-26 (1990-9) (in Japanese)

渋谷 真・江村克己・金井敏仁：「光ファイバ伝送を用いたマイク ロセル移動通信の無線信号集配方式」, 信学技報, SAT 90 29-40 pp.19-26 (1990-9)

(8) S.Kashimura, S.Shimizu, and Y.Kanaoka : "FP-LD Module for Micro-wave Wireless Access System Using Radio over Fiber Technique", Proceeding of Electronics, Information and Systems Conference Electronics, Information and Systems Society, I.E.E. of Japan, GS5-4 (2004-9) (in Japanese)

樫村 聡・清水 聡・金岡泰弘：「光電波融合技術を用いたマイク 口波带無線アクセスシステム用 FP-LD モジュールの試作」, 電気学 会 電子・情報・システム部門大会, GS5-4 (2004-9)

(9) Y.Kanaoka, S.Shimizu, and S.Kashimura : "BIDI Module for Micro-wave Wireless Access System using Radio on Fiber Technique", Proceeding of Electronics, Information and Systems Conference Electronics, Information and Systems Society, I.E.E. of Japan, GS5-3 (2004-9) (in Japanese)

金岡泰弘,・清水 聡・樫村 聡：「光電波融合技術を用いたマイク ロ波帯無線アクセスシステム用 BIDI モジュールの試作」, 電気学会 電子・情報・システム部門大会, GS5-3 (2004-9)

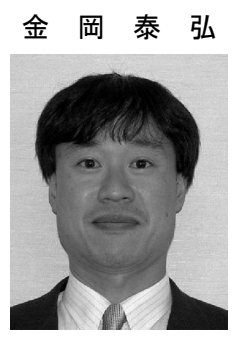

（正員） 1964 年 5 月 20 日生。 1987 年 3 月京 都大学工学部電気工学科卒業。1989 年 3 月同 大学院電子工学科修士課程修了。同年関西電力 (株)入社, 主として, 光通信, 無線通信の研究 開発に従事。現在, 同社電力技術研究所研究員。 1999 年電気学会電気学術振興賞, 進歩賞受賞

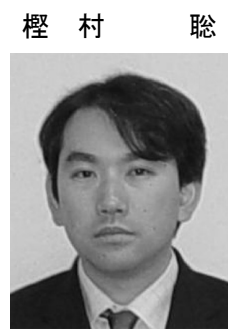

（正員） 1970 年 7 月 24 日生。 1994 年 3 月芝 浦工業大学工学部通信工学科卒業。1996 年同 大学院通信工学科修士課程修了。同年沖電気工 業(株)入社, 主として無線端末, ソフトウエア 無線, 光無線通信の研究開発に従事。現在，同 社無線技術研究開発部

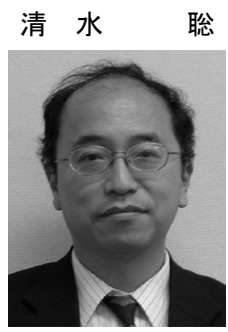

(非会員) 1963 年 7 月 17 日生。 1987 年 3 月 京都大学工学部電子工学科卒業。1995 年千葉 大学大学院自然科学研究科博士課程修了。1987 年沖電気工業(株)入社, 主としてディジタル信 号処理, 音響分析, 無線通信に関する研究開発 に従事。現在，同社無線技術研究開発部課長。 工学博士。1995 年海洋音響学会論文賞受賞 